\title{
Relationship between Monetary Organizations and Venture Performance of Women Entrepreneurs in the Colombo Mid-City, Sri Lanka.
}

\author{
H. K. G. S. Ranasinghe \\ ${ }^{*}$ Department of Entrepreneurship, Faculty of Management Studies and Commerce, University of Sri Jayewardenepura, Sri Lanka \\ DOI: 10.29322/IJSRP.11.06.2021.p11441 \\ http://dx.doi.org/10.29322/IJSRP.11.06.2021.p11441
}

\begin{abstract}
It is unspoken that insufficient investigation studies have been shown in the Sri Lanka on recognize the association between monetary and women entrepreneurs venture performance while Colombo Mid City is not well thought out in any of these. The main issue of the study is to examine if there is any association between Monetary Organizations and Venture Performance of Women Entrepreneurs in Colombo mid-City, Sri Lanka through this study. With the inadequate finances and the complicated process of formal monetary organizations as well as the inability to disrupt the slabs to elevate the women entrepreneur's venture performances, it is clear that women entrepreneurs come across numerous problems. Hence, monetary as a financial tool for women entrepreneurs can be regarded as a vital aspect. Therefore, the main objective of the study is to evaluate the association between monetary organizations and venture performance of women entrepreneurs. This research study covers the Colombo Mid City area in Sri Lanka. A sample of 122 women entrepreneurs were selected as respondents for the data collection done through a structured questionnaire. The convenient sampling technique was used in choosing the sample. Statistical Package for Social Sciences through reliability, factor, correlation and regression analysis were performed for the collected data. The findings indicated that monetary show a positive effect on the venture performance of women entrepreneurs in Colombo Mid City, Sri Lanka. However, the study findings were only based on Colombo Mid City, and did not represent the entire island. Therefore, future research need to focus on these aspects in order to improve the outcome of this type of research.
\end{abstract}

Index Terms- Monetary organizations, Savings, Training, Women entrepreneurs, Venture performance

\section{INTRODUCTION}

Monetary is a worldwide concept, which has a significance in Sri Lanka too (Rajapaksha, 2018). However, considering the constraints of accessing data from all over the country during a limited time, only the women entrepreneurs registered with monetary companies in Colombo Mid City, Sri Lanka were incorporated in this study. Therefore, the aim of this research is to identify the relationship between monetary factors and women entrepreneur's venture performance in Colombo Mid City, Sri Lanka and deliver required support for sustainable development of the women entrepreneurs.

There is a large number of monetary institutions in Sri Lanka, which provide different services to elevate the entrepreneurial venture performance. It is of prime importance to study the role of monetary on women entrepreneur's venture performance in Colombo Mid City during the current situation in the midst of the new trend. Over the past decade, the number of women starting their own businesses has grown intensely (Scholar, 2017). During 1970 and 1988, the percentage of women owned businesses were increased from approximately 5 percent to 30 percent in the United States (Swapna, 2017). United State Census Bureau showed that the number of women-owned businesses grew from 2.6 million in 1982, to 4.1 million in 1987, showing a 57.0 percent increased at present. Some authors and institutions projected that by the year 2000, almost 8 million women would have started their own companies (Omotayo, Ademola, \& Oluwayemi, 2017). No other country indicates such a large number of businesses started and owned by women, as in the United States. In order to understand the significance of this existing trend among women in the United States workforce and its impact to the nation's economy as a whole, conducting research on the personality characteristics of women entrepreneurs, the types of their businesses, and their reasons for doing so, can enlighten the world (Omotayo, Ademola, \& Oluwayemi, 2017).

Naturally, women business owners neither inherit family businesses nor buy established companies. It is more probable that they start their own businesses as fulfillment of the personal need, to attain one or more of personal goals such as personal freedom, security, and/or satisfaction of them (Sussan, \& Obamuyi, 2018). Women who have undergone certain type of frustration or dissatisfaction where they did paid work, like pay inequalities or discrimination during pregnancies, become freedom seekers. They tend to start their own ventures for them to have the independence to select the type of work, time of work, work settings, and the people 
they work with (Omotayo, Ademola, \& Oluwayemi, 2017). Self-employment provides the amenability with regard to the location such as working at home or close to home, and hours of work, which are the vital reasons for many women to become self-employed.

The "glass ceiling" that obstructs women's promotional opportunities in organizations, is a topic has been written extensively. For majority of women, the situation is to either acknowledge the glass ceiling or jump over it through entrepreneurship. Being tired of pay inequality, stagnant occupations, and dead-end jobs, many women tend to purchase franchises, be self-employed independent marketing representatives, or start their own careers and companies using the knowledge and skills gained working elsewhere. Women because of personal mishap, such as job layoff, downsizing, death of a family member, divorce, or retirement of their spouse, want to start a business for maintenance or improve their family social or economic status as security seekers (Wijewardana, \& Dedunu, 2017). While some draw attention to the insecurity of self-employment, others treat commercial downsizing, along with the uncertainty of Social Security and retirement funds to be similarly insecure. Many women in the present generation consider self-employment as an alternative retirement plan.

Furthermore, house wives with no earlier work experience, are inclined to be self-satisfied and prove others that they are useful and productive members of society by starting a business (Rajapaksha, 2018). Hence, women entrepreneurship is regarded to be one of vital concepts for a developing country like Sri Lanka (Wijewardana, \& Dedunu, 2017). The country has more than half of the women population, approximately 52 percentage, in comparison with the male population in Sri Lanka (Department of Census \& Statistics, 2020). However, the unemployment rate women in the country is higher in comparison with men. This situation is clearly depicted in the unemployed rate by age group and gender in the first quarter of 2020 in table 1.

Table 1: Unemployment Rate in sri Lanka - first quarter in 2020
\begin{tabular}{|l|l|l|l|l|}
\hline \multirow{2}{*}{ Age group } & \multicolumn{4}{|l|}{ Unemployment Rate in Sri Lanka } \\
\cline { 2 - 5 } & Number & Overall \% & Male \% & Female\% \\
\hline Sri Lanka & 483,172 & 5.7 & 3.7 & 9.6 \\
\hline $15-24$ & 266,743 & 26.8 & 21.1 & 36.3 \\
\hline $25-29$ & 94,561 & 11.6 & 7.1 & 18.9 \\
\hline Over 30 & 121,867 & 1.8 & 0.8 & 3.8 \\
\hline
\end{tabular}

(Source: Department of Census \& Statistics, 2020)

In all age groups, the unemployment among females is greater than males as survey results reveal. Overall unemployment in the country consist of a majority of youth and female unemployment. This pronounces the idle work force that could be exploited for the development of the country. Therefore, the growth of labor force participation of women become very important. The participation of women labor force can be done either by attracting more women in to labor force or by encouraging acting as women entrepreneurs. Inspiring women to be women entrepreneurs is certainly done in a several areas rather than endorsing them to labor force. The deficiency of women entrepreneurs has become the direct cause for their low levels of contribution to the economy (Department of Census \& Statistics, 2020). Considering this information the main problem of this study is to detect whether there is a link between monetary factors on the venture performance of women entrepreneurs in Colombo Mid City, Sri Lanka. Hence, the monetary organization factors were identified initially as a pathway to examine the connection with the performance women entrepreneurs' ventures in Colombo Mid City.

The convenient sampling method used by the researcher for the quantitative analysis of the study in order to ensure a sufficient representation of the overall population.

\section{IDENTIFY, RESEARCH AND COLLECT IDEA}

\section{Literature Review}

The recognition that entrepreneurship and entrepreneurs are identified as a major element of growth and reduction of poverty in rural and urban areas, while enterprises are referred to as "engine of growth" (Khaleque, 2018). Entrepreneurship as a kind of actions that constitute of initiative taking, organizing and reorganizing of social and economic mechanisms for converting resources and situations to practical version while facing risk or failure (Sussan \& Obamuyi, 2018). This acceptance has accelerated since the mid -1990s. Policy makers in many countries and international organizations initially to obviously identify the vital of the entrepreneurship and creation general statements about their hard work and entrepreneurial commitment to increasing entrepreneurship or, at least, to improving the entrepreneurial environment (OECD, 2007a). This is by emerging policies to expand the entrepreneurial growth whether by eliminating 
difficulties or via more direct directed actions (Ahmad \& Hoffman, 2007). Further, Ass, Gashi, \& Gashi (2019), recognize entrepreneurship to be a crucial part of economic development in any country. In addition, some academics believe that entrepreneurship serves everyone, especially women all over the world providing farfetched opportunities adequate to be self-sufficient, have self-esteem, and reach education and growth for them as well as their families (Diaka \& Asenge, 2019). In the meantime entrepreneurship is regarded to be an indispensable engine for economic growth, employment progress and converting dreams into financial opportunities which is a major concern of entrepreneurship (Ali, Khan, \& Asrar-Ul-Haq, 2019).

The explanation sets out to imprisonment a specific characteristic of entrepreneurship related precisely to business, since the welfares of the OECD and the organizations that have been contributing and supportive the OECD in this work are in this dominion (Ahmad \& Hoffman, 2007). The explanation reflects three components such as the definition of business entrepreneurs, meaning of entrepreneurial activities and word meaning of entrepreneurship. Business Entrepreneurs: Those peoples who have the ownership of the businesses pursue to create value, through the creation or expansion of economic activity by classifying and exploring new products, processes or markets. Entrepreneurial Activity: It is the innovative human action in pursuit of the creation of value, through the creation or expansion of economic activity, by identifying and exploiting products, process or markets. Entrepreneurship is the phenomenon associated with entrepreneurial activity (Ahmad \& Hoffman, 2007).

\section{Entrepreneurial Performance}

This measures the entrepreneurial action that are instrumental in delivering the impacts. Given the multitude of possible impacts, it follows that there is also a multitude of entrepreneurial indicators. Different countries will therefore choose to focus on different indicators of performance depending on their policy objective, which is the value they wish to create (Ahmad \& Hoffman, 2007; OECD, 2007a).

\section{Women Entrepreneurship}

Women entrepreneurship offers substantial contribution to the economic development in diverse ways when starting their own undertakings in different fields among numerous categories of entrepreneurship. A woman who creates, purchases or gains a business alone or with a collaborator tend to acknowledge risks, finances, regulations, social obligations and partakes in the daily management is accepted to be a women entrepreneur, her entrepreneur or women-head entrepreneur (Bouzekraoui \& Ferhane, 2017). An activity, which a woman or a group of women create to operate a business is also regarded as women entrepreneurship (Tola Zizile, 2018). It is clear that women entrepreneurship is growing in a fast pace within the countries while contributing considerably for generating employment opportunities and creating wealth in all economies (Agrawal, 2018). Females who possess finances or have talents or empowered with sufficient training in that specific field can also be grouped in to this category (Ass et al., 2019).

\section{Women Venture Performance}

It is a crucial act to measure the performance of a firm. Dzisi, Ofosu, Studies, Polytechnic, \& Polytechnic (2014) state the good performance need to be measured by evolving several calculable measures relevant to the features of the business activities which require enhancement and those which are successful during a set time period. The technique of measuring the efficiency and effectiveness of any action is known as performance measurement, which is the conversion of the intricate certainty of performance in planned symbols that can be followed in association under the identical situations (Ebrahim Mohammed Al-Matari, 2014).

The level of attainments of the entrepreneur can be known as performance. Both financial and non-financial parameters were used by academics to measure such accomplishments. Some of the variables that can be used to measure performance are sales growth, revenue growth and growth in the number of employees (Bouzekraoui \& Ferhane, 2017). Asheq \& Hossain (2019), explained that performance can also be measured by the variation in sales revenues and profit within previous three years, number of employees and alteration in customer base.

\section{Measurement of Women Venture Performance}

The performance can be measured by many methods. Annual sales, number of employees, return on sales, growth in sales, and growth in employee numbers are the most popular measures of performance (Danjuma, 2017). It is evident that both financial and non-financial measures are being used to measure the performance of a business enterprise. Sales revenue, profit before tax and turnover are the financial measures and features relating to customer satisfaction and employee turnover or creation of employment belong to nonfinancial measures (Diaka \& Asenge, 2019).

\section{Monetary Finance}

Monetary programs are launched with the target of reducing poverty and empowering women, and it is being recognized as a powerful and most effective tool for reducing poverty. The activity of providing financial services to patrons who do not get benefitted from the traditional financial system due to their lower economic status, is known as Monetary (Omotayo, Ademola S, \& Oluwayemi, 2017). It has been revealed that in comparison with the males, women entrepreneurs show a low business performance which can be due to monetary factors such as lack of credit, savings, networks and training (Swapna, 2017). 
Literature reveals that monetary concept is exclusive around the globe. Nevertheless, it is evident that programs and activities and which were successful in a particular country might not be successful likewise in another country primarily due to different socio economic conditions and ground situation among these countries (Bernard, Lock, Kevin, \& Khin, 2016). Monetary covers the delivery of financial services and the managing small quantities of money by way of products and a scheme of intermediate functions targeting low-income patrons (Diaka \& Asenge, 2019). Dame \& Adisa, (2020) recognize monetary as credit, savings and other financial services and further explain it to be provision of financial services to consumers and self-employed persons with low-income who possess slight banking knowledge or no access to banking and other related services.

The Consultative Group to Assist the Poor (CGAP) of the Central Bank of Sri Lanka defines monetary as "provision of financial services to low-income people". It comprises credit, savings and other essential financial services given to people who are considered to be economically disadvantageous to be assisted by regular banks, mainly due to lack of sufficient collateral.

\section{Monetary Credit}

Microcredit offers small loans to entrepreneurs who are not eligible for commercial bank credit. It is clear that providing sufficient credit supports entrepreneurship performance (Ekpe, 2010). Microcredit distributes small amounts of cash and loans in kind to micro, small entrepreneurs in order to improve their business activities (Danjuma, 2017). Amsi, Ngare, Imo, \& Gachie, (2017) describe monetary credit to be a source of funding while it plays an important part in poverty mitigation leading to the progress of SMEs. While Arif (2017) believes that credit is given as aid to entrepreneurs, particularly women which in turn helps to increase their income, investment, output and welfare. Danjuma, (2017) identifies micro credit as a type of small loan given for individuals having low income and generally without any security, steady job and verifiable wealth at all.

It has been revealed that patrons who obtained more Monitory Financial Institutions loans of high average size, showed enhanced growth rates than other enterprises (Diaka \& Asenge, 2019). Credit as loan repayment period, sum received, the researcher has regarded repayment method and required security as indicators to measure the performance.

\section{Monetary Organization Savings}

Savings are described as the income not spent or utilized for consumption (Amsi, Ngare, Imo, \& Gachie, 2017). In recent times the savings mobilization has been identified as a major strength in monetary. Saving services act as a very important device for clients in managing liquidity issues through availability of cash, rate of return, security and disability (Amsi, Ngare, Imo, \& Gachie, 2017). Savings serve an important and worthy foundation to monetary, as funds that can be easily gained with a minimum cost, withdrawal of small sum of money from saving account do not expose to liquidity risk as against large borrowings and monetary institutions can improve their operations through deposit-taking by creating a strong market-demand (Al-shami et al., 2013). The women entrepreneurs were able to face severe crisis through their savings, managed to cope up with the shocks, reduced vulnerability, and even purchased property that can be sold during a crucial times; savings assist to obtain another monetary cycle and also to commence and develop the current micro enterprise processes (Diaka \& Asenge, 2019).

Danjuma, (2017) expresses the view that micro-savings help less affluent people to save as they can do it weekly as well as provide to group savings while monetary institutions can utilize these savings for providing more loans to other customers. Savings can be explained as keeping a portion of current income safely for future consumption or investing. Entrepreneurs are encouraged by monetary banks, to save money with them, in order to empower them to invest in entrepreneurial ventures (Diaka \& Asenge, 2019).

\section{Monetary Organization Trainings}

Financial services by itself cannot enhance the progress while it has shown that micro-credit can really be meaningful when linked with training which is an indispensable necessity for creating sturdy and self-confident entrepreneurs who could facilitate the progress of their businesses (Shehu, Ahmad, \& Al-Aidaros, 2015). Mandipaka (2014) specified that women generally have no access to training and experience on ways and means of business processes, which makes them incapable of providing market goods and services strategically. Training is planned to enhance skills, knowledge and attitude with the objective of getting entrepreneurs to commence a new venture or enlarge an existing business (Mayuran, 2016).

Training helps to provide solutions to issues in relation to small ventures mainly problem-solving, venture management, time limitation and creation of new ideas (Hechavarria, Bullough, Brush, \& Edelman, 2019). Further, he believes that micro-enterprise success has a positive link with training. Since many women entrepreneurs in low-income countries do not have access to training, monetary banks deliver training especially to women (Diaka \& Asenge, 2019).

\section{Monetary Organization Credits}

Different scholars have described the association between micro credit and venture performance in diverse ways. Yogendrarajah (2016), explained that there is a positive link between microcredit and women empowerment. It is further indicated that microcredit is important as an instrument for the development of women entrepreneurship and elaborated that non-credit aspects too serve a vital role for improving their performance. Furthermore, credit amount, interest rate, collateral requirement and repayment period have been taken by other scholars to explain the relationship between microcredit and business performance. SME financial performance is found to be 
significantly affected by credit amount, interest rate, collateral requirement but credit repayment method does not have any noteworthy impact on performance. (Amsi et al., 2017)

\section{Relationship between Monetary Organization Factors and the Women Entrepreneurship}

Only few studies available in the Sri Lankan context on this subject to be considered as empirical evidence. Wijewardana \& Dedunu, (2017), conducted a study in Mihinthale Pradeshiya Sabha area, to evaluate the effect of monetary on empowerment of women entrepreneurship. The accessibility to loans, repayment process and non-financial services were taken as independent variables in this study. The results of this study revealed that statistically significant impact is shown by loan accessibility, repayment procedure and non-financial services on women empowerment in Mihinthale Pradeshiya Sabha Area. The study also endorses that financial institutes should also bring about awareness among women to empower them in relation to financial management, market identification, customer services and savings procedure. Bernard et al. (2016), specified that entrepreneurial success of women entrepreneurs has a positive relationship with micro-credit and micro-savings. Although the academics have acknowledged micro-insurance to be an important feature of monetary services, the insurance schemes articulated to settle the unpaid loans of the women entrepreneurs do not meet the requirements. Hence, no proper link has been shown between micro-insurance and entrepreneurial progress of women entrepreneurs. Yogendrarajah, (2016), examined the effect of micro finance factors on the performance of women entrepreneurs in the Northern Sri Lanka. The results of this study indicated that micro finance factors such as credit, savings and training have a positive effect on and business performance. Furthermore, it was evident that in the Northern part of Sri Lanka, out of the three variables, savings performed a striking part in the business performance of women entrepreneurs. Another conclusion of this study was that building social awareness, self-confidence along with education and proper skill training among women need to accompany credit provision.

\section{Methodology}

This study emphasizes on venture performance of women entrepreneurs as dependent variable, and Monetary as independent variable as illustrated below.

\section{A Conceptual Framework}

Cconceptual framework demonstrates the expectations of the researcher on conducting the research and the manner in which the variables might relate to each other. Figure 1 indicates the conceptual model of this study based on the literature review.

\section{Independent Variable}

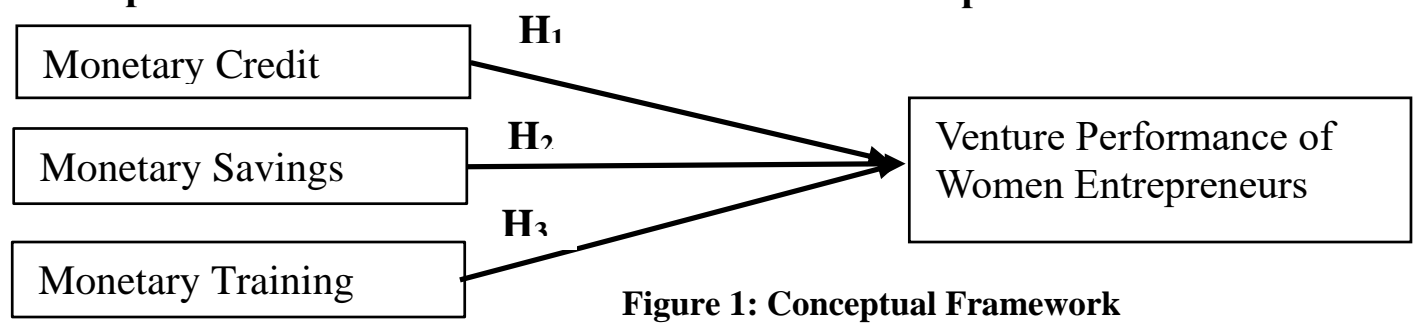

\section{Hypotheses Formulation}

Hypothesis 1: H1: There is an association between monetary loan services and the venture performance of women entrepreneurs in Colombo Mid City, Sri Lanka.

Hypothesis 2: H2: There is an association between monetary saving services and the venture performance of women entrepreneurs in Colombo Mid City, Sri Lanka.

Hypothesis 3: H3: There is an association between monetary training services and the venture performance of women entrepreneurs in Colombo Mid City, Sri Lanka.

\section{The Statistical Analysis}

\section{WRITE DOWN YOUR STUDIES AND FINDINGS}

The statistical analysis attempts to find an answer to the question of the study. Hence, it is very important to have an enriched knowledge of the measurement pertinent to the data analysis. Table 2 present the test of the normality of the data as follows.

Table 2: Test of Normality

\begin{tabular}{lcccccc}
\hline \multirow{2}{*}{ Variables } & \multicolumn{3}{c}{ Kolmogorov-Smirnov $^{\text {a }}$} & \multicolumn{3}{c}{ Shapiro-Wilk } \\
\cline { 2 - 7 } & Statistic & Df & Sig. & Statistic & Df & Sig. \\
\hline Credit Facility & 0.151 & 122 & 0.000 & 0.948 & 122 & 0.000 \\
\hline
\end{tabular}




\begin{tabular}{lllllcc}
\hline Savings Facility & 0.177 & 122 & 0.000 & 0.936 & 122 & 0.000 \\
Training Facility & 0.206 & 122 & 0.000 & 0.908 & 122 & 0.000 \\
Venture performance -Financial & 0.139 & 122 & 0.000 & 0.939 & 122 & 0.000 \\
Venture performance - Non & 0.204 & 122 & 0.000 & 0.875 & 1222 & 0.000 \\
Financial & & & & & & \\
\hline
\end{tabular}

The sig. value of Kolmogorov-Smirnov test and the Shapiro-Wilk test need to be greater than 0.05 in order to adopt the normality of data. However as shown in table 3 all variables have sig values less than 0.05 . Therefore the assumption of normality for the data set is not satisfied.

Table 3: Reliability Test with Cronbach's Alpha Value

\begin{tabular}{lcc}
\hline \multicolumn{1}{c}{ Variables } & N of Items & Cronbach's Alpha Value \\
\hline Credit Facility & 7 & 0.854 \\
Savings Facility & 6 & 0.953 \\
Training Facility & 7 & 0.944 \\
Venture performance -Financial & 7 & 0.940 \\
Venture performance - Non & 7 & 0.931 \\
Financial & & \\
\hline
\end{tabular}

The KMO values indicate sampling adequacy of each variable. In order to consider as valid data KMO values need to be greater than 0.5. The results show that all variables satisfied the required level of adequacy.

\section{Correlation Analysis}

Correlation analysis can be performed by using bivariate analysis to find the relationship between dependent and independent variables. Correlation coefficient explains the relationship strength in value and whether the relationship is positive or negative. Since the results of the normality test indicated Skewness and Kurtosis values were in required range, expressing that data were normally distributes, researcher could use the Pearson correlation-two tailed test to measure the relationship.

A perfect positive association between the two variables is shown by a value of exactly 1.0 while a perfect negative relationship is demonstrated by value of -1.0. A value between 0-0.2 indicates a weak or no relationship, 0.2- 0.4 stipulates weak link, 0.4- 0.6 specifies moderate connection, 0.6-0.8 shows a strong association while a coefficient between 0.8- 1.0 identifies a very strong relationship between variables. Table 4 presents the Correlation Matrix of data.

Table 4: Correlations Matrix

\begin{tabular}{|c|c|c|c|c|c|}
\hline \multicolumn{6}{|c|}{ Correlations } \\
\hline & & $\begin{array}{c}\text { Venture } \\
\text { performanc } \\
\mathrm{e}\end{array}$ & $\begin{array}{l}\text { Total } \\
\text { Credit } \\
\text { Facility }\end{array}$ & $\begin{array}{l}\text { Total } \\
\text { Savings } \\
\text { Facility }\end{array}$ & $\begin{array}{c}\text { Total } \\
\text { Entrepreneu } \\
\text { rial Training }\end{array}$ \\
\hline Venture & Pearson & 1 & $.340^{* *}$ & $.507^{* *}$ & $.721^{* *}$ \\
\hline \multirow[t]{3}{*}{ Performance } & Correlation & & & & \\
\hline & Sig. (2-tailed) & & .000 & .000 & .000 \\
\hline & $\mathrm{N}$ & 122 & 122 & 122 & 122 \\
\hline \multirow[t]{4}{*}{ Total Credit Facility } & Pearson & $.340^{* *}$ & 1 & $.182^{*}$ & .173 \\
\hline & Correlation & & & & \\
\hline & Sig. (2-tailed) & .000 & & .045 & .057 \\
\hline & $\mathrm{N}$ & 122 & 122 & 122 & 122 \\
\hline Total Savings & Pearson & $.507^{* *}$ & $.182^{*}$ & 1 & $.192^{*}$ \\
\hline \multirow[t]{3}{*}{ Facility } & Correlation & & & & \\
\hline & Sig. (2-tailed) & .000 & .045 & & .034 \\
\hline & $\mathrm{N}$ & 122 & 122 & 122 & 122 \\
\hline Total & Pearson & $.721^{* *}$ & .173 & $.192^{*}$ & 1 \\
\hline Entrepreneurial & Correlation & & & & \\
\hline \multirow[t]{2}{*}{ Training } & Sig. (2-tailed) & .000 & .057 & .034 & \\
\hline & $\mathrm{N}$ & 122 & 122 & 122 & 122 \\
\hline
\end{tabular}


The results of this study reveals that all the independent variables demonstrate positive association with the dependent variable at the significant level of 0.01 (2 tailed test).

The correlation results reveal a weak positive relationship between Credit Facility and Venture Performance with 0.340 and sig value as at 0.000 level. Saving Facility and Venture Performance divulge a moderate positive relationship with a correlation of 0.507, while a strong positive relationship is disclosed between Training Facility and Venture Performance due to 0.721 coefficient at 0.000 sig level. Therefore, the results prove that intensification of Credit Facility, Saving Facility and Training Facility leads to enhanced Venture Performance of the women entrepreneurs in the Colombo Mid city in Sri Lanka.

\section{Discussion}

The correlation analysis of monitory credit facility and venture performance of women entrepreneurs demonstrate a weak positive relationship with a value of 0.340 , which is significant at 5 percent level of significance. This led the researcher to perform the multivariate analysis in the future too. Henceforth, a positive association is indicated by monitory credit on venture performance of women entrepreneurs supporting the hypothesis one of this study. This is supporting the hypothesis one and accepted. Thus, the empirical results of the study supported the proposed relationship between Monetary Facility of credit on venture performance of women entrepreneurs Hussain \& Basheer (2017) too regarded credit facility as an important monetary factor for developing the venture growth and run the business successfully and working capital required by women entrepreneurs. Findings of Mayuran (2016) propose that women entrepreneurship activities show a week relationship associated by credit needs received from monetary organizations. There is an association between monetary loan service facilities on the venture performance of women entrepreneurs is the second hypothesis of the study. The correlation analysis gave a correlation value of 0.507 with a sig value of 0.000 which is less than 0.05 indicating a moderate positive relationship between monetary saving facilities and venture performance of women entrepreneurs. Since the correlation analysis was significant at 5 percent level of significance it supports the regression analysis to be performed for with the independent variable, monetary savings too. This proves that the second hypothesis that there is an association between monetary saving services on the venture performance of women entrepreneurs can be accepted. Thus, the empirical results of the study supported the proposed relationship between Monetary Facility of services on venture performance of women entrepreneurs A strong positive correlation with a value of 0.721 indicated between monetary training and venture performance of women entrepreneurs in the correlation analysis and it was signified at 5 percent level of significance. This evidence initiated the researcher to implement the multivariate analysis too. This is supporting the hypothesis three and accepted. Thus, the empirical results of the study supported the proposed relationship between Monetary Facility of training on venture performance. Rotiche, Laget \& Kogei (2013) are also of the view that the venture performance of women entrepreneurs are enhanced by systematic savings of women entrepreneurs of their ventures. This study revealed that training services provided by the monetary banks have significant effect on the performance of womenowned SMEs. This result is in agreement with findings of the study done by Oni (2012) which exposed that small and medium scale entrepreneurs in Nigeria have gained better skills from training and skills development activities received from monetary institutions. Muiruri (2014) expressed the same finding of the study supporting these results.

\section{CONCLUSION}

The relationship between monetary organizations and the venture performance of women entrepreneurs was examined by this study. The Findings revealed that monetary organizations services have a significant association on improving the venture performance of Women Entrepreneurs in Colombo Mid City Sri Lanka. It is evident from a study that venture performance in enterprises of Women Entrepreneurs has a more significant relationship by the monetary organizations providing the training facility rather than the credit facilities and saving facilities. The study also concludes that the skills and experience of women have significantly improved by training services offered by monetary organization, which were transferred to their enterprises.

\section{Recommendation}

Based on the findings of the study, it can be recommended that female entrepreneurs in Colombo Mid City should be provided credit facilities with low interest rates by monetary organizations, in order to inspire them to expand their businesses and run the businesses successfully. In order to avoid client's frustration and moving to other sources of unworthy credit, monetary organizations should improve their timely payments plans especially for the loans. Further monetary banks are required expand their savings facilities for the products using different strategies to retain the clients. As some monetary organization have limited number of products and this helps to address that challenge. It is also important that monetary organizations need to provide training to female entrepreneurs on appropriate business practices to avoid business failures. Further, it is appropriate that monetary organization conduct training needs assessment among the clients to detect the type of training is suitable for entrepreneurs. Acquiring sufficient human capital to the businesses could be performed through educating the women entrepreneurs in a suitable manner. Therefore, this study recommends improving knowledge of monetary facilities to develop the businesses of women entrepreneurs. 


\section{Implications}

It is evident that women entrepreneurs have a substantial contribution to the economy of a country. Therefore, any encouragement given to them towards entrepreneurship will cause tremendous progress in the near future. Therefore, the implications of this study will serve the society in many ways. This information serve as a foundation to Entrepreneurs in a country to have an awareness on the on new ventures. Further policy makers can make use of this material to take vital decisions for the development of the country.

The study provides the knowledge of monetary services in Colombo Mid City, Sri Lanka, in addition to the operation of micro credit, savings and training among women entrepreneurs in the same area. Furthermore, this provides details of the problem areas in the existing monetary products that have less effect on venture performance enabling the Monetary Institutions to reconsider their strategies and make relevant improvements to their products. Eventually, this can be based on for future research studies. The women entrepreneurs can expand any further research on this area to include other vital micro financial services that influence the start-up process and launch businesses. Moreover, research could be extended to cover the entire island without restricting it to a specific area.

\section{Limitations}

The sample was limited to Colombo Mid City, Sri Lanka, and this was a limitation as the results from a specified area was generalized to entire country. The researcher was unable to incorporate the sample size as decided, due to the existing pandemic situation. Accuracy of answers by respondents was another limitation that was surfaced in the study. In general, people do not always provide facts but occasionally give bias answers, which was a common limitation found when collecting data through questionnaire. Finally, the study was limited to questionnaire data due to the current situation in the country.

\section{REFERENCES}

[1] Agrawal, R. (2018). Constraints And Challenges Faced By Women Entrepreneurs In Emerging Market Economy And The Way Forward. Jwee, (3-4), 1-19. https://doi.org/10.28934/jwee18.34.pp1-19

[2] Al-shami, S. S. A., Bin, I., Majid, A., Rashid, N. A., Syaiful, M., \& Bin, R. (2013). Conceptual Framework: The Role of Microfinance on the Wellbeing of Poor Conceptual Framework: The Role of Microfinance on the Wellbeing of Poor People Cases Studies from Malaysia and Yemen. (December). https://doi.org/10.5539/ass.v10n1p230

[3] Ali, H. Y., Khan, M. K., \& Asrar-Ul-Haq, M. (2019). Factors affecting the performance of women entrepreneurs in SMEs: A case study of Punjab, Pakistan. Journal for International Business and Entrepreneurship Development, 12(1), 67-82. https://doi.org/10.1504/JIBED.2019.103366

[4] Ahmad. N. and Anders Hoffman, (2007), A Framework for addressing and Measuring Entrepreneurship, OECD, Paris

[5] Amsi, F., Ngare, P., Imo, P., \& Gachie, M. (2017). Effect of Microfinance Credit on SMEs Financial Performance in Kenya The Catholic University of Eastern Africa Corresponding Author : Philip Ngare. 8(1), 48-61.

[6] Asheq, A. Al, \& Hossain, M. U. (2019). SME performance : Impact of market, customer and brand orientation. Academy of Marketing Studies Journal, 23(1), $1-9$.

[7] Ass, P., Gashi, R., \& Gashi, H. (2019). CHALLENGES OF FEMALE ENTREPRENEURS IN TRANSITION COUNTRIES : CASE STUDY OF KOSOVO. 68-77.

[8] Bernard, D. T. K., Lock, L., Kevin, T., \& Khin, A. A. (2016). Entrepreneurial Success through Microfinance Services among Women Entrepreneurs in Sri Lanka : A Pilot Study and Overview of the Findings. 6(3), 1144-1150.

[9] Bouzekraoui, H., \& Ferhane, D. (2017). An Exploratory Study of Women's Entrepreneurship in Morocco. Journal of Entrepreneurship: Research \& Practice, 2017, 1-19. https://doi.org/10.5171/2017.869458

[10] Bryman and Bell, C. a. (2006). RESEARCH METHODOLOGY.

[11] Dame, S., \& Adisa, A. O. (2020). The Impact Of Microfinance Banks On The Income Level Of Women Beneficiaries In Central And Northern Taraba After Joining The Microfinance Institutions. IOSR Journal of Economics and Finance, 11(2), 17-24. https://doi.org/10.9790/5933-1102011724

[12] Danjuma, D. (2017). Impact of Microfinance Services on Performance of Small and Medium Scale Enterprises (SMEs) In Zaria Metropolis. 2(1), 49-65.

[13] Diaka, H., \& Asenge, E. (2019). Effect of Microfinance Banks on the Performance of Selected Women-Owned Enterprises in Makurdi Metropolis, Benue State, Nigeria. The International Journal of Business Management and Technology, , 39-46.

[14] Dzisi, S., Ofosu, D., Studies, M., Polytechnic, K., \& Polytechnic, K. (2014). Marketing Strategies and the Performance of SMEs in Ghana. 6(5), $102-111$.

[15] Ebrahim Mohammed Al-Matari, F. H. (2014). The Measurements of Firm Performance's Dimensions. Asian Journal of Finance \& Accounting, $24-49$.

This publication is licensed under Creative Commons Attribution CC BY.

http://dx.doi.org/10.29322/IJSRP.11.06.2021.p11441

WWW.ijsrp.org 
[16] Hechavarria, D., Bullough, A., Brush, C., \& Edelman, L. (2019). High-Growth Women's Entrepreneurship: Fueling Social and Economic Development. Journal of Small Business Management, 57(1), 5-13. https://doi.org/10.1111/jsbm.12503

[17] Khaleque, A. (2018). Performance of Women Entrepreneurs : Does Access to Finance Really Matter? 11(21), $23-48$.

[18] Mandipaka, F. (2014). An investigation of the challenges faced by women entrepreneurs in developing countries: A case of king williams' town, South africa. Mediterranean Journal of Social Sciences, 5(27), 1187-1193. https://doi.org/10.5901/mjss.2014.v5n27p1187

[19] Mayuran, L. (2016). Impact of Entrepreneurship Training on Performance of Small Enterprises in Jaffna District Problem Statement and Research Questions Entrepreneurship training financial management Performance of Small enterprises. Global Journal of Commerce \& Management Perspective, 5(2), 1-6. Retrieved from www.gifre.org

[20] MUIRURI, P. M. (2014). The Role of Micro-Finance Institutions to the Growth of Micro and Small Enterprises (MSE) in Thika, Kenya (Empirical Review of Non-Financial Factors). International Journal of Academic Research in Accounting, Finance and Management Sciences, 4(4), $249-262$. https://doi.org/10.6007/ijarafms/v4-i4/1342

[21] OECD (2007a), Micro-polices for Growth and Proctivity, available at www.oecd.org./ sti/micro-policies

[22] Omotayo, I. A., Ademola S, S., \& Oluwayemi, O. (2017). ROLE OF MICROFINANCE ON THE PERFORMANCE. International Journal of Innovative Research and Knowledge, 13-28.

[23] Rajapaksha, R. P. (2018). Challenges for Female Entrepreneurship in Sri Lanka. International Journal of Science and Research (IJSR), 1235-1239.

[24] Scholar, M. P. (2017). Combination of Microcredit and Micro-Training with Mediating Role of Formal Education : A Micro-Enterprise Success Formula. 3(2), 285-291.

[25] Shehu, F. M., Ahmad,, H. B., \& Al-Aidaros, A.-H. (2015). A Proposed Framework on the Relationship between Islamic Microfinance Related Factors and Women Entrepreneurs Business Performance in Nigeria. Journal of Education and Vocational Research, 38-44.

[26] Swapna, K. (2017). Impact of Microfinance on Women Entrepreneurship. 7(1), 229-241.

[27] Tola Zizile, C. T. (2018). The Importance Of Entrepreneurial Competencies On The Performance Of Women Entrepreneurs In South Africa .

[28] Wijewardana, W. P., \& Dedunu, H. H. (2017). Impact of Microfinance to Empower Female Entrepreneurs. International Journal of Business Marketing and Management (IJBMM, 2(7), 1-6. Retrieved from www.ijbmm.com

[29] Yogendrarajah, R. (2016). Micro Credit is a Tool for Women Entrepreneurship Development. (September 2015). https://doi.org/10.17265/2159$5291 / 2015.09 .005$

\section{Biographical Sketch}

Dr. Sriyani Ranasinghe is a Senior Lecturer at the Department of Entrepreneurship, Faculty of Management Studies and Commerce, University of Sri Jayewardenepura, Sri Lanka. She is currently serving as the Head of the Department of the Department of Entrepreneurship. She obtained her Bachelors in Management Studies degree with a first class from the Open University of Sri Lanka. She has obtained the Master of Science in Organizational Management postgraduate degree from University of Peradeniya, and followed up with a PhD in Business Management from Management and Science University in Malaysia. Her passion is teaching and doing many CSR on behalf of the community.

\section{Email: hksri@sjp.ac.lk}

\section{Mob: +94007 6500518}


International Journal of Scientific and Research Publications, Volume 11, Issue 6, June 2021

This publication is licensed under Creative Commons Attribution CC BY. 